Onkologie 1985;8(suppl. 1):1

\title{
Inhalt, Vol. 8, Supplement 1, 1985
}

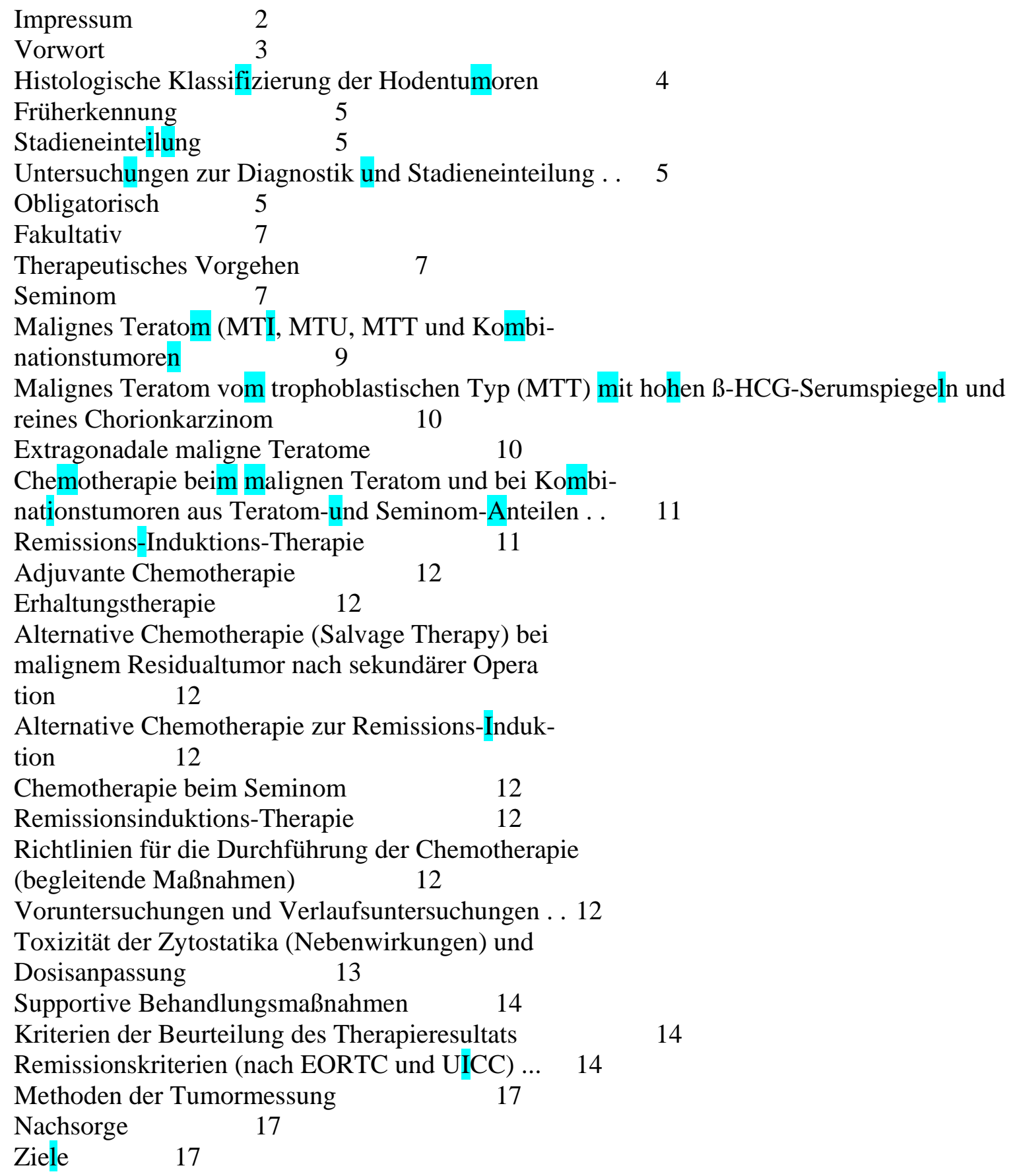




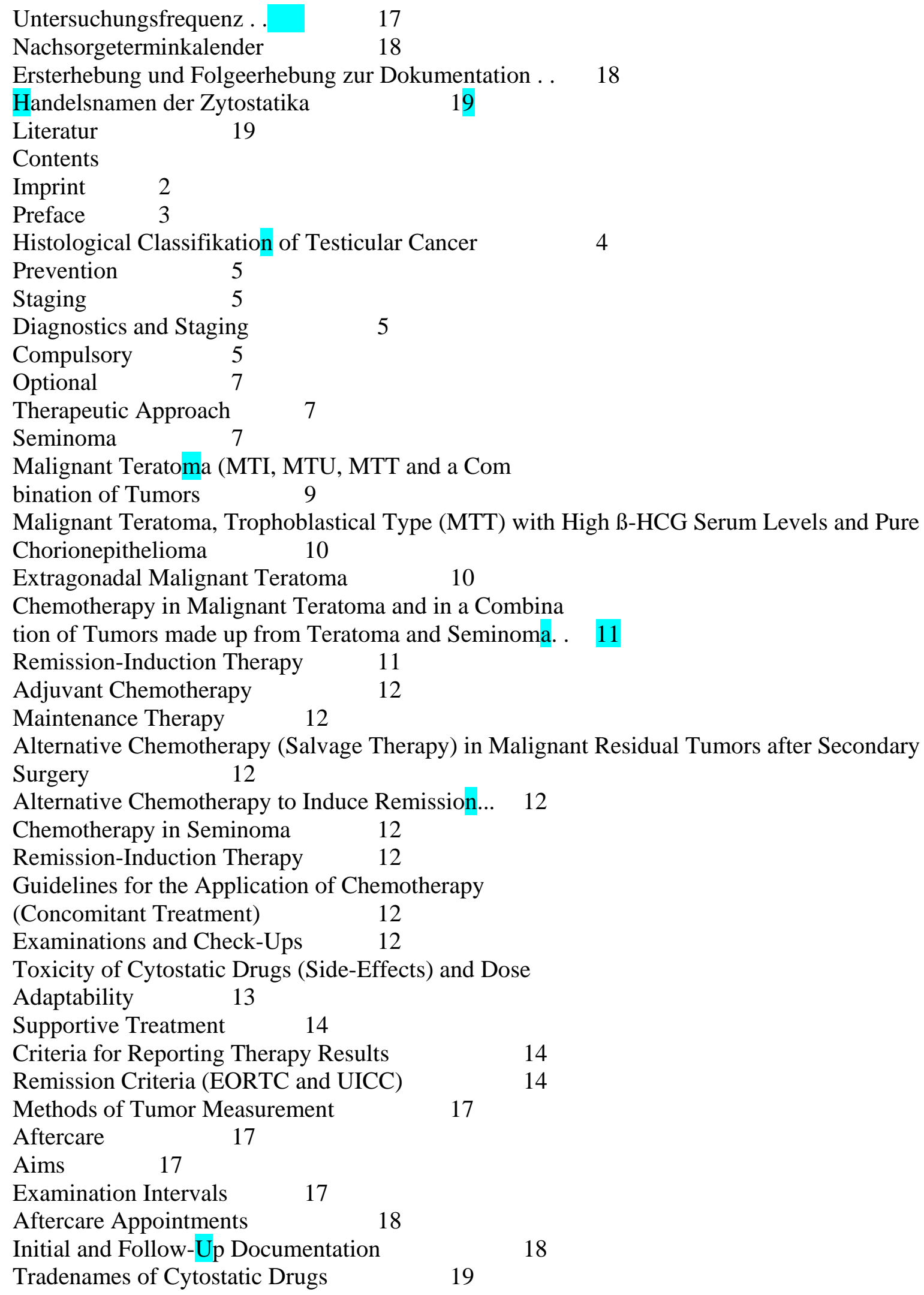


References

19

Bibliographischer Hinweis: Inhaltsverzeichnisse dieser Zeitschrift erscheinen regelmäßig in current contents ${ }^{\circledR}$ sowie in anderen bibliographischen Diensten. 